\title{
TANGGUNG JAWAB SEKUTU MAATSCHAP TERHADAP PIHAK KE 3 DALAM SUATU PERJANJIAN KONSORSIUM TERKAIT BUBARNYA MAATSCHAP ATAS KEHENDAK PARA SEKUTU (Kasus Perjanjian Konsorsium antara PT Agro Bintang Dharma Nusantara dengan Pemerintah Daerah Balikpapan, Bontang, Kutim dan Paser)
}

\section{Responsibility Ally Maatschap to Third Parties in the Consortium Agreement Relating Unraveling Maatschap for Ally Discretion (Case Consortium Agreement between Dharma Nusantara PT Agro Star and Local Government Balikpapan, Bontang, East Kutai and Paser)}

\author{
Julius Caesar Transon Simorangkir \\ Fakultas Hukum Universitas Gadjah Mada \\ email : jc_transon14@yahoo.com
}

\begin{abstract}
The development of society in the field of economy requires laws to regulate economic problems. Scientific developments in the field of economy should be accompanied by regulations that govern them. Dynamic human life resulted in a pattern of life that compound so that the interests of each individual is different, if not set or laid out by the law, there will be cheating in any transaction or trade activity. In the case of procurement of ferry quickly conducted a consortium of several regions in Borneo as Balikpapan, Bontang, Paser, and east Kutai PT Argo Stars Darma Nusantara in terms of cooperation agreements number 021/ABDN-Dir/SPK/X/01 dated October $4^{\text {th }}, 2001$, for the provision of services fast boats "water jet ferry" Trans East Kalimantan. Based on the above cases occur inequality allies in terms of responsibility to third parties, due to the dissolution of the consortium agreement by the will of some allies. Section 1646, Book IV of the Civil Code to determine the various ways the end of an alliance, one of which is the fellowship ended due to the will of one or several parties. The termination agreement also automatically terminates the agreement made by the parties. However, responsibility for third party does not necessarily come to an end. Responsibility towards third parties stipulated in Article 16421645 .
\end{abstract}

Keywords: Responsibility Allies, to third parties, the Consortium Agreement 


\section{abstrak}

Perkembangan masyarakat di bidang perekonomian mengharuskan hukum untuk mengatur persoalan ekonomi. Perkembangan keilmuan di bidang perekonomian sebaiknya disertai dengan peraturan yang mengaturnya. Kehidupan manusia yang dinamis mengakibatkan pola kehidupan yang majemuk sehinga kepentingan pada setiap individu berbeda-beda, jika tidak diatur atau ditata oleh hukum maka akan terjadi kecurangan dalam setiap transaksi atau ativitas perdagangannya. Pada kasus pengadaan kapal feri cepat yang dilakukan secara konsorsium dari beberapa daerah di Kalimantan seperti Balikpapan, Bontang, Paser, dan Kutai timur dengan PT Argo Bintang Darma Nusantara dalam hal melakukan perjanjian kerja sama nomor 021/ABDN-Dir/SPK/X/01 tanggal 4 Oktober 2001, untuk pengadaan jasa pelayanan kapal cepat "water jet feri" Trans Kalimantan Timur. Berdasarkan kasus diatas terjadi ketimpangan para sekutu dalam hal tanggung jawab kepada pihak ketiga, disebabkan bubarnya perjanjian konsorsium oleh kehendak beberapa orang sekutu. Pasal 1646, Buku ke IV KUHPerdata menentukan mengenai macam-macam cara berakhirnya suatu persekutuan, salah satunya yaitu persekutuan berakhir dikarenakan karena kehendak salah satu atau beberapa pihak. Berakhirnya kesepakatan secara otomatis juga mengakhiri perjanjian yang dibuat oleh para pihak. Namun, tanngung jawabnya terhadap pihak ke 3 tidak serta merta berakhir. Tanggung jawab terhadap pihak ketiga diatur pada pasal 1642-1645.

\section{Kata Kunci: Tanggung Jawab Sekutu, Pihak ke 3, Perjanjian Konsorsium}

\section{A. Pendahuluan}

Manusia merupakan mahkluk sosial, disebabkan sifat dasar dari manusia itu sendiri yang selalunya hidup dalam berkelompok sehingga dari kelompok-kelompok tersebut muncullah interaksi diantara anggota kelompok. Manusia berkerjasama dalam pemenuhan kebutuhan hidupnya sehari-hari. Interaksi yang dilakukan dalam masyarakat bisa merupakan halhal yang menyenangkan dan hal-hal yang tidak menyenangkan. Interaksi yang dapat menyebabkan ketidak harmonisan dalam masyarakat diatur dalam kaidah-kaidah yang tumbuh dan berkembang dalam masyarakat. Suatu hal yang tidak wajar kehidupan bersama dalam masyarakat tidak diatur oleh hukum (ubi societas ibi jus; di mana ada masyarakat ada hukum.) kehidupan bersama dalam masyarakat selalunya terdapat kaidah-kaidah sosial yang hidup dan berkembang dalam masyarakat.

Diferensiasi kepentingan dalam masyarakat mengakibatkan hukum hadir untuk melindungi kepentingan kepentingan manusia dalam bermasyarakat. Manusia yang satu merupakan serigala bagi manusia yang 
lain (homo homini lupus) ${ }^{1}$. Manusia selalunya memunyai ambisi untuk berkuasa dan menang sendiri mengedepankan ego, sehingga hukum hadir untuk mengatur tatanan kehidupan dalam masyarakat.

Hukum yang bersifat dinamis dan statis, selalu memberikan kepastian hukum kepada masyarakat dalam penegakan atau pemberian sanksi kepada individu yang melanggar hukum. Sanksi dimaksudkan untuk menjaga stabilitas dan mengembalikan kerusakan (restitutum in integrum). Hukum bersifat dinamis, Hukum berkembang mengikuti perkembangan masyarakat. Saham terbesar dalam perkembangan hukum yaitu masyarakat.

Perkembangan masyarakat di bidang perekonomian mengharuskan hukum untuk mengatur persoalan ekonomi. Menurut Romli Atmasasmita ${ }^{2}$ seharusnya memasukkan mata kuliah khusus yang membahas tentang analisis ekonomi tentang hukum (Economic Analysis of Law). Untuk mencegah terjadinya ketidakpastian dalam penegakan hukum yang berkaitan dengan ekonomi. Perkembangan keilmuan di bidang perekonomian sebaiknya disertai dengan peraturan yang mengaturnya. Pengadaan barang dan jasa yang merupakan ranah hukum privat dalam praktiknya melibatkan pihak publik olehnya membutuhkan suatu peraturan yang mengaturnya.

Pengadaan barang dan jasa yang dilakukan secara konsorsium diatur dalam Keputusan Presiden No. 54 Tahun 2010 tentang Pengadaan Barang dan Jasa/Pemerintah dalam Pasal 21 ayat 1 "Dalam hal sifat dan lingkup kegiatan Pengadaan Barang/Jasa terlalu luas, atau jenis keahlian yang diperlukan untuk menyelesaikan kegiatan tidak dapat dilakukan oleh 1 (satu) Penyedia Barang/Jasa, maka dalam pelaksanaan Pengadaan Barang/Jasa diberikan kesempatan yang memungkinkan para Penyedia Barang/Jasa saling bergabung dalam suatu konsorsium atau bentuk kerja sama lain.

Dasar hukum pengadaan barang dan jasa secara konsorsium dituangkan dalam Keppres, sehingga sudah seharusnya para pihak yang melakukan kerjasama pengadaan barang dan jasa mematuhi Keppres tersebut. Pengadaan barang dan jasa yang dilakukan dalam masyarakat tidak jarang terjadi berbagai pelanggaran terhadap peraturan yang berlaku bahkan terjadi yang namannya cacat janji, dan tidak ada alasan yang meringankan atau yang dapat dijadikan alasan untuk melepaskan diri dari tuntutan ingkar janji tersebut. Hal yang dapat dijadikan atau dikategorikan sebagai wanprestasi.

Wanprestasi (kelalaian atau kealpaan) seorang debitur dapat berupa empat macam ${ }^{3}$ :

a. tidak melakukan apa yang disanggupi akan dilakukannya;

\footnotetext{
${ }^{1}$ Sudikno Mertokusumo, Teori Hukum, (Yogyakarta: Atma Jaya Yogyakarta, 2012), hlm. 21.

${ }^{2}$ Romli Atmasasmita, Hukum Kejahatan Bisnis (Teori dan Praktik di Era Globalisasi), (Bogor: Kencana, 2014), hlm. 19.

${ }^{3}$ Subekti, Hukum Perjanjian, (Jakarta: PT Intermasa, 2005), hlm. 45.
} 
b. melaksanakan apa yang dijanjikan, tetapi tidak sebagaimana dijanjikan;

c. melakukan apa yang dijanjikan tetapi terlambat;

d. melakukan sesuatu yang menurut perjanjian tidak boleh dilakukan.

Kategori wanprestasi di atas ketika dilakukan maka, dapat dikatakan sebagai wanprestasi serta bisa dilakukan penuntutan terhadap janji yang telah disepakati. Hal di atas dapat dikecualikan atau dilakukan pembelaan serta tidak dapat dikatakan wanprestasi sebagaimana tercantum dalam KUHPerdata, terdiri dari: alasan keadaan memaksa (overmacht atau force majeur), alasan kreditur lalai memenuhi prestasinya (Execptio Non Adimpleti Contractus ), dan alasan kreditur telah melepaskan haknya untuk menuntut ganti kerugian (rechtsverwerking).

Kehidupan manusia yang dinamis mengakibatkan pola kehidupan yang majemuk sehinga kepentingan pada setiap individu berbeda-beda, jika tidak diatur atau ditata oleh hukum maka akan terjadi kecurangan dalam setiap transaksi atau aktivitas perdagangannya. Pada kasus pengadaan kapal feri cepat yang dilakukan secara konsorsium dari beberapa daerah di Kalimantan seperti Balikpapan, Bontang, Paser, dan Kutai Timur dengan PT Argo Bintang Darma Nusantara dalam hal melakukan perjanjian kerja sama nomor 021/ABDN-Dir/SPK/X/01 tanggal 4 Oktober 2001, untuk pengadaan jasa pelayanan kapal cepat "water jet feri" Trans Kalimantan Timur. Kapal direncanakan untuk alat transportasi yang akan menghubungkan empat daerah tersebut. Di dalam perjanjian itu, menyatakan bahwa para pihak sepakat untuk melaksanakan pengadaan jasa pelayanan kapal cepat dengan total biaya investasi sebesar AS \$4 juta (sekitar Rp 40 miliar). Masingmasing pihak yang melakukan kerja sama menginvestasikan sebesar 20\% dengan kewajiban penyertaan modal masing-masing AS $\$ 800.000$ atau sekitar IDR 8,2 Miliar. Kapal yang dibeli tidak dapat beroperasi secara maksimal dan hanya dapat dipakai sekali karena keadaannya yang tidak layak. Diketahui pula ternyata kapal yang dibeli tidak sesuai dengan kesepakatan awal, karena ternyata kapal tersebut merupakan kapal bekas yang dibeli dari Belanda. Pada pelaksanaanya, layanan kapal feri cepat kalah bersaing dengan sarana transportasi murah ditawarkan maskapai penerbangan, sehingga menimbulkan kerugian. Persoalan ini, juga yang akhirnya membebani keuangan Pemkot Balikpapan.

Badan Pemeriksa Keuangan selalu mencantumkan investasi kapal feri cepat dalam opini audit keuangan daerah tiap tahunnya, sehingga membuat Balikpapan selalu mendapat opini wajar dengan pengecualian (WDP) karena pengadaan kapal itu. Akhirnya, pihak pemerintah kota Kalimantan Timur (Kaltim) membawa kasus kapal feri cepat (KFC) ke jalur hukum agar terkait rekomendasi Pansus DPRD Balikpapan adanya penyimpangan dalam pengadaan kapal tersebut, dan menilai bahwa investasi KFC tersebut gagal. Kejaksaan Negeri Balikpapan bahkan sempat menangani kasus ini serta 
menjebloskan Direktur PT Agro Bintang, Budi Handoko ke sel tahanan. Namun pengadilan membebaskan terdakwa ini dari tuntutan kasus korupsi dijeratkan jaksa penuntut umum.

Fakta lain yang ditemukan, ternyata PT BKT ini hanya memunyai akte pendirian perseroan, tidak ada SIUP (Surat Izin Usaha Perdagangan), tidak ada NPWP (Nomor Pokok Wajib Pajak), termasuk tidak terdaftar di Kementerian Hukum dan HAM. Bersamaan dengan hal tersbut, maka hal ini menjadi alasan empat daerah konsorsium yakni Balikpapan, Paser, Bontang dan Kutai Timur (Kutim) untuk sepakat membubarkan PT. Bintang Kaltim Transport selaku operator KFC itu. Bahkan kesepakatan pembubaran perusahaan itu diketahui Gubernur Kaltim. Empat daerah konsorsium tersebut selanjutnya, akan membentuk tim bersama untuk melelang KFC itu, kemudian hasil lelang itu dibagi ke masing-masing daerah, dengan meminta tenaga apraisal untuk menilai pembagiannya.

Berdasarkan kasus di atas terjadi ketimpangan para sekutu dalam hal tanggung jawab kepada pihak ketiga, disebabkan bubarnya perjanjian konsorsium oleh kehendak beberapa orang sekutu. Berdasarkan latar belakang di atas, maka dapat diambil rumusan masalah sebagai berikut: 1) Bagaimana tanggung jawab para sekutu Maatschap terhadap pihak ke-3 dalam hal bubarnya perjanjian konsorsium oleh kehendak beberapa orang sekutu?; dan 2) Apakah dapat pihak ke-3 menuntut pengajuan tuntutan kepada konsorsium dalam hal terjadi kerugian?

\section{B. Pembahasan}

\section{Kasus Posisi}

Kasus ini bermula dari perjanjian konsorsium antara pemerintah daerah Balikpapan, Bontang, Kutim, dan Paser dengan PT Agro Bintang Dharma Nusantara (ABDN) dalam hal melakukan perjanjian kerja sama Nomor 021/ABDN-Dir/SPK/X/01 tanggal 4 Oktober 2001, untuk pengadaan jasa pelayanan kapal cepat "water jet feri" Trans Kalimantan Timur. Kapal direncanakan untuk alat transportasi antara empat daerah tersebut. Di dalam perjanjian itu, menyatakan bahwa para pihak sepakat untuk melaksanakan pengadaan jasa pelayanan kapal cepat dengan total biaya investasi sebesar AS \$4 juta (sekitar Rp 40 miliar). Masing-masing pihak yang melakukan kerja sama memiliki saham $20 \%$ dengan kewajiban penyertaan modal masing-masing AS $\$ 800.000$ atau sekitar IDR 8,2 Miliar. Untuk mengelola usaha kapal feri cepat itu, dibentuklah PT Bintang Kaltim Transport berdasarkan Akte Pendirian PT Pelayanan Bintang Kaltim Transport (BKT) nomor 35 tanggal 12 Maret 2002, dengan dana IDR 400 juta untuk pendirian PT BKT tersebut.

Berdasarkan Putusan Mahkamah Agung Nomor 507K/Pid/2005 tanggal 18 April 2007, diketahui Pemkab Kutim telah menerbitkan Surat 
Perintah Membayar Uang (SPMU) Nomor 324/PT/2001 dengan nilai IDR 8,2 Miliar tanggal 22 November 2001. Kemudian dana tersebut ditransfer kepada PT Agro Bintang Dharma Nusantara. Namun, dalam pelaksanaan yang terjadi DPRD Balikpapan menemukan investasi gagal kapal feri cepat (KFC) sebesar IDR 42 Miliar. Kapal yang dibeli tidak dapat beroperasi secara maksimal dan hanya dapat dipakai sekali karena keadaannya yang tidak layak. Diketahui pula ternyata kapal yang dibeli tidak sesuai dengan kesepakatan awal, karena ternayata kapal tersebut merupakan kapal bekas yang dibeli dari Belanda.

Pada pelaksanaanya, layanan kapal feri cepat kalah bersaing dengan sarana transportasi murah ditawarkan maskapai penerbangan, sehingga menimbulkan kerugian. Persoalan ini, juga yang akhirnya membebani keuangan Pemkot Balikpapan. Badan Pemeriksa Keuangan selalu mencantumkan investasi kapal feri cepat dalam opini audit keuangan daerah tiap tahunnya, sehingga membuat Balikpapan selalu mendapat opini wajar dengan pengecualian (WDP) karena pengadaan kapal itu. Akhirnya, pihak Pemerintah Kota Kalimantan Timur (Kaltim) membawa kasus kapal feri cepat (KFC) ke jalur hukum agar terkait rekomendasi Pansus DPRD Balikpapan adanya penyimpangan dalam pengadaan kapal tersebut, dan menilai bahwa investasi KFC tersebut gagal. Kejaksaan Negeri Balikpapan bahkan sempat menangani kasus ini serta menjebloskan Direktur PT Agro Bintang, Budi Handoko ke sel tahanan. Namun pengadilan membebaskan terdakwa ini dari tuntutan kasus korupsi dijeratkan jaksa penuntut umum.

Fakta lain yang ditemukan, ternyata PT BKT ini hanya memunyai akte pendirian perseroan, tidak ada SIUP (Surat Izin Usaha Perdagangan), tidak ada NPWP (Nomor Pokok Wajib Pajak), termasuk tidak terdaftar di Kementerian Hukum dan HAM. Bersamaan dengan hal tersbut, maka hal ini menjadi alasan empat daerah konsorsium yakni Balikpapan, Paser, Bontang dan Kutai Timur (Kutim) untuk sepakat membubarkan PT. Bintang Kaltim Transport selaku operator KFC itu. Bahkan kesepakatan pembubaran perusahaan itu diketahui Gubernur Kaltim. Empat daerah konsorsium tersebut selanjutnya, akan membentuk tim bersama untuk melelang KFC itu, kemudian hasil lelang itu dibagi ke masing-masing daerah, dengan meminta tenaga apraisal untuk menilai pembagiannya.

\section{Tinjauan Umum Mengenai Persekutuan Perdata/ Maatschap a. Pengertian Pesekutuan Perdata/Maatschap}

Menurut pandangan klasik, maatschap merupakan bentuk genus (umum) dari persekutuan Firma dan persekutuan Komanditer/CV. Bahkan menurut pandangan klasik, maatschap tersebut mulanya merupakan bentuk genus pula dari Perseroan Terbatas (PT). Konsekuensi jika firma dan CV sebagai bentuk Maatschap, maka keduanya juga memiliki karakteristik- 
karakteristik dari maatschap, sepanjang tidak diatur secara khusus dan menyimpang dalam KUHD. Dengan demikian dapat disimpulkan bahwa apa yang diatur dalam KUHPerdata mengenai Maatschap berlaku pula terhadap Firma dan CV. Keadaan ini ditentukan dalam pasal 15 KUHD, yang menyatakan bahwa persekutuan-persekutuan yang disebut dalam Buku I Bab III, bagian I KUHD, diatur oleh perjanjian-perjanjian anatara para pihak dan oleh KUHPerdata. Sebenarnya, apa yang diatur dalam Pasal 15 KUHD sejalan dengan apa yang diatur dalam Pasal 1 KUHD. Sebab KUHD itu sendiri merupakan spesies dari KUHPerdata yang merupakan genus-nya. ${ }^{4}$

Dalam kepustakaan dan ilmu hukum, istilah persekutuan bukanlah istilah tunggal, karena ada istilah pendampingnya yaitu perseroan dan perserikatan. Ketiga istilah ini sering digunakan untuk menerjemahkan istilah bahasa Belanda Maatschap dan vennootschap. Maat maupun Vennoot dalam bahasa aslinya (Belanda) berarti kawan atau sekutu. Istilah persekutuan terjemahan dari kata maatschap (partnership) yang berarti dua orang atau lebih mengikatkan diri untuk memberikan sesuatu berupa uang, barang atau tenaga dalam bentuk suatu kerjasama. ${ }^{5}$

Beberapa penulis lain menerjemahkannya sebagai persekutuan perdata atau perserikatan perdata. Persekutuan artinya persatuan orang-orang yang sama kepentingannya terhadap suatu perusahaan tertentu. Sedangkan sekutu artinya peserta dalam persekutuan. Jadi, persekutuan berarti perkumpulan orang-orang yang menjadi peserta pada perusahaan tertentu. Jika badan usaha tersebut tidak menjalankan perusahaan, maka itu bukanlah persekutuan perdata, tetapi disebut perserikatan perdata. Sedangkan orangorang yang mengurus badan itu disebut sebagai anggota, bukan sekutu. Dengan demikian, terdapat dua istilah yang pengertiannya hampir sama, yaitu perserikatan perdata dan persekutuan perdata. Perbedaannya, perserikatan perdata tidak menjalankan perusahaan, sedangkan persekutuan perdata menjalankan perusahaan. Dengan begitu, maka perserikatan perdata adalah suatu badan usaha yang termasuk hukum perdata umum, sebab tidak menjalankan perusahaan. Sedangkan persekutuan perdata adalah suatu badan usaha yang termasuk dalam hukum perdata khusus (hukum dagang), sebab menjalankan perusahaan. ${ }^{6}$

Selain itu, perlu juga dibedakan antara persekutuan dengan perkumpulan. Meski keduanya di dalam BW merupakan cara kerjasama antara para peserta untuk mencapai suatu tujuan, tetapi ada perbedaan didalamnya. Perbedaannya adalah persekutuan dengan tegas dan selaku titik

\footnotetext{
${ }^{4}$ Mulhadi, Hukum Perusahaan (Bentuk-Bentuk Badan Usaha di Indonesia), (Bogor: Penerbit Ghalia Indoensia, 2010), hlm. 34.

${ }^{5}$ M. Yahya Harahap, Hukum Perseroan Terbatas, Cet IV, (Jakarta: Sinar Grafika, 2013), hlm. 4.

${ }^{6}$ Op.Cit., Mulhadi, hlm. 36.
} 
beratnya pada mengejar keuntungan dalam hal perbendaan. Sedangkan dalam perkumpulan tujuannya terletak pada hal lain yang bukan merupakan keuntungan, misalnya berada di lapangan kerohanian, pendidikan, profesi, kebudayaaan seperti perkumpulan tari-tarian, perkumpulan advokat, dan sebagainya. ${ }^{7}$

Batasan yuridis maatschap dimuat dalam Pasal 1618 KUHPerdata, yang dirumuskan sebagai berikut: Persekutuan perdata adalah suatu persetujuan dengan mana dua orang atau lebih mengikatkan diri untuk memasukkan sesuatu (inbreng) dalam persekutuan dengan maksud untuk membagi keuntungan yang terjadi karenanya.

\section{b. Jenis-Jenis dan Sifat Pendirian Maatschap}

Sesuai dengan Kitab Undang-undang Hukum Perdata sebagai sumber hukumnya, maatschap itu terbagi dua, yaitu maatschaap umum dan maatschap khusus. Maatschap Umum (Pasal 1622 KUHPerdata) meliputi apa saja yang akan diperoleh para sekutu sebagai hasil usaha mereka selama maatschap berdiri. Maatschap jenis ini usahanya bisa bermacam-macam (tidak terbatas), yang penting inbreng-nya ditentukan secara jelas. Maatschap khusus (Pasal 1623 KUHPerdata) adalah maatschap yang gerak usahanya ditentukan secara khusus, bisa hanya mengenai barang-barang tertentu saja, atau pemakaiannya, atau hasil yang akan didapat dari barangbarang itu, atau mengenai suatu usaha tertentu atau penyelenggaraan suatu perusahaan atau pekerjaan tetap. Jadi, penentuannya ditekankan pada jenis usaha yang dikelola oleh maatschap (umum atau khusus), bukan pada inbrengnya. Mengenai pemasukan, baik pada maatschap umum maupun maatschap khusus harus ditentukan secara jelas atau terperinci. Kedua maatschap ini dibolehkan, yang tidak dibolehkan adalah maatschap yang sangat umum yang inbrengnya tidak diatur secara terperinci, seperti yang disinggung oleh Pasal 1621 KUHPerdata. ${ }^{8}$

Menurut Pasal 1618 KUHPerdata, maatschap adalah persekutuan yang didirikan atas dasar pejanjian. Menurut sifatnya, perjanjian itu ada dua macam golongan, yaitu perjanjian konsensual dan perjanjian riil. Perjanjian mendirikan maatschap adalah perjanjian konsensual, yaitu perjanjian yang terjadi karena ada persetujuan kehendak dari pihak atau ada kesepakatan sebelum ada tindakan-tindakan (penyerahan barang). Pada maatschap, jika sudah ada kata sepakat dari para sekutu untuk mendirikannya, meskipun belum ada inbreng, maka maatschap sudah dianggap ada.

\footnotetext{
${ }^{7}$ Djoko Prakoso \& Bambvang Riyadi, Dasar Hukum Persetujuan Tertentu di Indonesia, (Jakarta: PT. Bina Aksara, 1987), hlm. 120.

${ }^{8}$ Op.Cit., Mulhadi, hlm. 37.
} 
Undang-undang tidak menentukan mengenai cara pendirian maatschap, sehingga perjanjian maatshap bentuknya bebas. Tetapi dalam praktik, hal ini dilakukan dengan akta otentik ataupun akta di bawah tangan. Juga tidak ada ketentuan yang mengharuskan pendaftaran dan pengumuman bagi maatschap, hal ini sesuai dengan sifat maatshap yang tidak menghendaki adanya publikasi (terang-terangan)

Perjanjian untuk mendirikan maatschap, di samping harus memenuhi ketentuan dalam pasal 1320 KUHPerdata, juga harus memenuhi syaratsyarat sebagai berikut.

1) tidak dilarang oleh hukum;

2) tidak bertentangan dengan tatasusila dan ketertiban umum; dan

3) harus merupakan kepentingan bersama yang dikejar, yaitu keuntungan.

\section{c. Kemitraan di Common Law dan Civil Law System}

Persekutuan perdata sering pula dikenal dengan kemitraan, karena ada entitas sekutu didalamnya. Kemitraan atau persekutuan perdata, maatschap atau vennootschap (dalam bahasan Belanda), partnership (dalam bahasa Inggris). Sedangkan dalam khasanah hukum Islam dikenal dengan istilah shirkah. Kesemuanya merupakan suatu bentuk dasar kegiatan bisnis. Pengertian bisnis di sini adalah segala aktivitas dalam bidang perdagangan dan pekerjaan atau profesi. Sebagai bentuk kegiatan bisnis yang maksud pendiriannya untuk memasukkan modal, keahlian dan kemampuan dalam suatu perusahaan dalam rangka untuk membagi keuntungan yang telah disepakati.

Bentuk kegiatan bisnis berkembang di Negara Comman Law maupun Civil Law. Sistem Civil Law yang dianut oleh negara-negara Eropa Kontinental seperti Belanda, Jerman, Perancis, Italia dll. Sedangkan sistem Common Law dianut oleh negara-negara Anglo Saxon, seperti Inggris, Amerika. Malaysia, India, Australia dll. Keduanya memiliki titik tekan tersendiri di mana Civil Law lebih menitik beratkan kepada penegakan hukum/rechtstastaat, sementara Common Law menitikberatkan kepada keadilan hukum.

Merujuk pada definisi kemitraan tentang kemitraan di Inggris yang menganut Civil Law dijelaskan dalam Pasal 1 Partnership Act 1890, yaitu hubungan antara orang yang menjalankan kegiatan bisnis dengan tujuan untuk mendapatkan keuntungan. Sementara di Malaysia, dalam Pasal 3 (1) Akta Perkongsian 1961, kemitraan yang diistilahkan sebagai pengkongsian, yaitu perhubungan yang wujud antara orang-orang yang menjalankan perniagaan. ${ }^{9}$ Sedangkan di dalam hukum Belanda, Vennotschapsretchts

\footnotetext{
${ }^{9}$ Ridwan Khairandi, Pokok-Pokok Hukum Dagang Indonesia, (Yogyakarta: FH UII Press, 2013), hlm. 27.
} 
diterjemahkan lebih sempit dibanding di negera yang menganut Common Law. Hukum Belanda dalam menerjemahkan Vennotshapsretchts hanya sebatas pada NV, Firma dan CV diatur dalam KHUHD. Sedangkan pengaturan mengenai persekutuan pedata di mana menjadi induk dari padanya diatur dalam KUHPerdata. Artinya, persekutuan perdata adalah bentuk umum dari kerjasama dalam bentuk persekutuan. Sedangkan bentuk khususnya dari perjanjian persekutuan ini adalah CV dan firma. Kemitraan atau yang lebih dikenal dengan persekutuan perdata terdapat dalam Pasal 1618 KUHPerdata, yaitu perjanjian antara dua orang atau lebih mengikatkan diri untuk memasukkan sesuatu (inbrengen) ke dalam persekutuan dengan membagi keuntungan yang diperoleh karenanya.

Dengan melihat perkembangan hukum kemitraan antara Common Law dan Civil Law yang memiliki perbedaan sistem hukum sudah barang tentu berbeda pula akibat hukumnya.

\section{1) Hukum Kemitraan di Common Law}

Dalam sistem hukum Common Law, kemitraan adalah suatu perkumpulan yang terdiri pemilik dan pengurus dengan tujuan untuk memperoleh keuntungan yang mempunyai tanggung jawab penuh dalam menjalankannya. Kemitraan dalam praktiknya adalah suatu perkumpulan yang tidak bisa dipisahkan secara hukum di mana para mitranya diberi hak sama untuk mendapatkan keuntungan dari usahanya tersebut. Kemitraan memiliki bentuk yang berbeda. Bentuk khusus dari kemitraan didasarkan atas bentuk-bentuk bisnis dalam sistem hukum Cicil Law. Sedangkan kemitraan terbatas lebih banyak ditemukan di Negara Common Law.

Bahkan Komisi Hukum negara-negara pada tahun 1914, yang terdiri atas hakim, jaksa dan akademisi hukum telah mengesahkan Undang-Undang tentang Kemitraan. Sebagaimana yang telah disebutkan dalam Pasal 1 Partnership Act 1890 tentang Kemitraan, maka dapat disimpulkan bahwa kemitraan memiliki karakteristik sebagai berikut: ${ }^{10}$

a) kemitraan bukan merupakan perusahaan yang terdaftar berdasarkan ketentuan perundang-undangan perusahaan melainkan hukum perjanjian;

b) timbul karena adanya keinginan untuk mengadakan hubungan konsensual di mana keinginan itu timbul bukan karena diatur oleh undang-undang melainkan karena kehendak para pihak;

c) selalu melibatkan unsur modal, keahlian atau gabungan antara keduanya;

d) pada umumnya menjalankan suatu kegiatan bisnis yang terdiri atas perusahaan dan mitranya; dan

e) dibentuk untuk memperoleh keuntungan bagi parak pihak.

${ }^{10}$ Ibid., hlm. 27. 
Mengingat kemitraan adalah suatu kesepakatan antar pihak untuk mengerjakan suatu kegiatan bisnis, maka kemitraan dapat dibedakan menurut jenisnya sebagai berikut ${ }^{11}$ :

a) General Partnership adalah kemitraan yang timbul didasarkan atas hubungan secara umum dari berbagai macam bentuk bisnis. General Partnership mengandung makna seperti persekutuan perdata. Dalam konteks hukum Indonesia memiliki kesamaan dengan firma;

b) Specific Partnership atau Limited Partnership adalah kemitraan yang timbul karena satu bentuk transaksi khusus. Mitra jenis ini memiliki kesamaan dengan CV yang dipraktekkan di Indonesia. Yaitu suatu kemitraan yang terdiri atas satu orang atau lebih mitra yang memasukkan modal dan tidak mengelola bisnis serta hanya bertanggung jawab sejumlah pemasukannya;

c) Trading Partnership yaitu kemitraan yang dengan sengaja dibentuk untuk tujuan frofit oriented melalui pembelian maupun penjualan di bidang perdagangan barang;

d) Non Trading Partnership yaitu kemitraan yang dibentuk untuk kegiatan non komersial, seperti kerjasama dalam bidang kedokteran;

e) Nominal Partnership yaitu kemitraan dimana di antara mereka pada dasaranya bukan mitra tetapi dberikan ijin untuk bergabung dalam bisnis dan dalam waktu tertentu dapat menjadi mitra tetap;

f) Secret Partnership yaitu suatu kemitraan di antara mereka ambil bagian dalam manajemen perusahaan tetapi orang lain tidak mengetahuinya bahwa ia merupakan bagian dari mitra; dan

g) Dormant Partnership yaitu mareka yang tidak ambil bagian dalam manajemen dan orang lain mengetahuinya.

Adapun bentuk dari kemitraan yang berkembang di negara Common Law sebagaimana yang tertuang dalam Undang-Undang tentang Kemitraan Terbatas tahun 1907, Mitra Umum yaitu suatu kemitraan aktif di mana selain para pihak menanamkan modalnya dan mendapatkan keuntungan juga memunyai hak untuk berpartisipasi dalam manajemen usaha dan tanggung jawabnya tidak terbatas dalam hal hutang kemitraan kepada kreditor. Maksudnya, ketika perusahaan memunyai hutang kepada kreditor dan ketika jatuh tempo tidak mampu melunasi maka kreditor berhak menagih kepada para mitra lainnya. Mitra umum sering dikenal dengan mitra aktif. Sedangkan, Mitra terbatas yaitu kemitraan yang ikut menanamkan modal dan mendapat pembagian keuntungan tetapi tidak ikut berpartisipasi dalam manajemen kemitraan dan memunyai tanggung jawab yang terbatas. Artinya, tanggung jawab para pihak terbatas pada jumlah modal yang

${ }^{11}$ Johannnes Ibrahim, Hukum Organisasi Perusahaan: Pola Kemitraan dan Badan Hukum, (Bandung: Refika Aditama, 2006), hlm. 27-29. 
disetorkan kepada perusahaan. Adapun kemitraan tidak sanggup untuk melunasi hutangnya kepada kreditor ketika jatuh tempo maka kreditor tidak dapat meminta mitra terbatas untuk melunasinya.

Perjanjian kemitraan bisa dilakukan secara lisan atau tertulis. Namun perjanjian yang dilakukan secara tertulis memiliki kekuatan karena ketika terjadi hal yang tidak diinginkan antar para pihak dapat dijadikan sebagai bukti hukum. Sebagaimana yang disebutkan di atas bahwa kemitraan adalah suatu perjanjian, maka perjanjian kemitraan disebut pula dengan istilah "The Partnership Agreement”. Artinya, para pihak dapat melakukan kesepakatan untuk mengerjakan kegiatan bisnis sebagaimana tertuang dalam perjanjian yang dibuatnya.

Sebagai subyek hukum, para pihak dalam kemitraan memiliki hak dan kewajiban. Adapun hak para pihak dalam kemitraan adalah sebagai berikut:

a) hak untuk mendapatkan kompensasi atas pelayanan kemitraan (Pasal 21 UPA/ The Uniform Partnership Act);

b) hak untuk mendapatkan ganti rugi atas pengeluaran dalam menjalankan kegiatan bisnis (Pasal 18 (b) UPA);

c) hak untuk memperoleh pengembalian modal ketika suatu kemitraan dibubarkan (Pasal 18 (d) UPA);

d) modal di sini merupakan segala bentuk uang dan kelengkapan kemitraan yang didistribusikan oleh para mita secara tetap yang digunakan oleh kemitraan;

e) hak untuk memperoleh pengembalian pinjaman dari mitra itu sendiri di mana pinjaman tersebut harus sudah dibedakan dengan modal kemitraan (Pasal 18 (c) UPA); dan

f) hak untuk mendapatkan informasi yang berkaitan dengan kegiatan kemitraan.

Sedangkan kewajiban para mitra;

a) berkewajiban untuk menepati perjanjian yang telah disepakati dan bertanggung jawab ganti rugi ketika melanggar perjanjian;

b) berkewajiban untuk bertanggung jawab atas kegiatan bisnis yang dijalankan dan mempunyai kepedulian antar sesame mitra; dan

c) berkewajiban untuk memberikan informasi yang relevan dengan kemitraan (Pasal 20 UPA).

Adapun ketika salah satu mitra meninggal dunia, maka mitra yang meninggal dunia tersebut tetap mendapatkan haknya yang diambilkan dari kekayaan kemitraan bukan dari aset kemitraan.

\section{2) Hukum Kemitraan di Civil Law}

Kemitraan di negara Civil Law juga mengalami perkembangan sangat pesat. Hal ini sama halnya dengan kemitraan di negara Common Law. 
Adapun kemitraan di negara Civil Law seperti Indonesia dikenal dengan seperti :

a) Firma

Mollengraff mendefinisikan firma adalah suatu perkumpulan yang didirikan untuk menjalankan perusahaan di bawah nama bersama dan yang mana anggota-anggotanya tidak terbatas tanggung jawabnya terhadap perikatan perseroan dengan pihak ketiga. ${ }^{12}$ Kata firma mengandung arti nama yang digunakan secara bersama-sama dalam berdagang. Perihal nama bersama yang digunakan sebagai nama suatu organisasi bisnis pada dasarnya memiliki kesamaan antara Indonesia dengan yang berkembang di Anglo Saxon. Namun dalam perkembangannya firma banyak digunakan untuk menjalankan kegiatan profesi dari pada untuk kegiatan komersial dalam bidang perdagangan. Hal ini terjadi lantaran para pengusaha lebih memilih bentuk kemitraan komanditer atau perseroan terbatas. Melihat pengertian di atas, paling tidak firma mengandung unsur-unsur pokok antara lain:

i. persekutuan perdata (Pasal 1618 KUHPerdata);

ii. menjalankan perusahaan (Pasal 16 KUHD);

iii. dengan nama bersama (Pasal 16 KHUD); dan

iv. tanggung jawab mitra bersifat pribadi untuk keseluruhan atau tanggung renteng.

Pendirian firma dapat dibentuk dengan membuat akta pendirian oleh mereka yang mendirikannya, di mana akta pendirian tersebut didaftarkan di Kepaniteraan Pengadilan Negeri di daerah mana firma tersebut berdomisili dan tidak diharuskan mendaftarkan ke Kementrian Hukum dan Hak Asasi Manusia (Pasal 23 KUHD).

\section{b) Commanditaire Vennootschap (CV)}

Pengertian CV atau persekutuan komanditer dapat dilihat Pasal 19 (1) dan (2) KUHD yaitu persekutuan secara melepas uang yang dinamakan persekutuan komanditer, didirikan antara satu orang atau beberapa sekutu yang secara tanggung menanggung bertanggung jawab untuk seluruhnya pada pihak satu dan satu orang atau lebih sebagai pelepas uang pada pihak lain. Dilihat dari ketentuan KUHD di atas, pada dasarnya persekutuan komanditer merupakan persekutuan firma yang memunyai satu atau beberapa orang sekutu komanditer. Adapun karakteristik dari persekutuan komanditer dapat dibedakan menjadi dua sekutu kompelementer/aktif dan sekutu komanditer/pasif. Sekutu komplementer atau sekutu aktif merupakan sekutu yang secara aktif mengurus aktivitas kegiatan bisnis perusahaan, memiliki hubungan hukum dengan pihak ketiga dan bertanggung jawab secara pribadi untuk keseluruhan. Sedangkan, sekutu komanditer atau sekutu

${ }^{12}$ Ibid., hlm. 34. 
pasif tidak mengurus $\mathrm{CV}$, namun wajib menyerahkan uang, benda, keahlian kepada persekutuan sebagaimana yang telah diperjanjikan, serta berhak menerima keuntungan. Tanggung jawab dari sekutu pasif terbatas pada jumlah modal yang disetorkan pada perusahaan. Oleh karena, tanggung jawabnya yang terbatas, sekutu pasif dilarang ikut campur dalam kepengurusan sekutu komplementer atau sekutu aktif (Pasal 20 KUHD). Apabila peraturan ini dilanggar maka tanggung jawabnya menjadi tanggung jawab pribadi untuk keseluruhan (Pasal 21 KUHD).

Dengan demikian, dapat ditarik kesimpulan bahwa kemitraan atau persekutuan perdata baik di negara Comman Law atau Civil Law memiliki kesamaan. Kesamaannya terletak pada hubungan para mitra yang didasarkan pada perjanjian. Dengan kata lain, kemitraan ketentuannya tunduk pada hukum perjanjian.

Melihat hal itu, kemitraan pada dasarnya suatu kegiatan bisnis yang didasarkan pada perjanjian oleh para mitra dalam rangka untuk memperoleh keuntungan. Karena lebih didominasi oleh hukum perjanjian, maka dalam kemitraan tidak ada pemisahan kekayaan antara kemitraan dengan mitra. Konsekuensinya terdapat pada tanggung jawab para mitra tidak terbatas. Hal inilah yang membedakan bahwa kemitraan bukan merupakan badan hukum. Namun demikian, kemitraan dipahami sebagai suatu wadah yang sengaja dibentuk untuk menjalankan kegiatan bisnis yang bersifat komersial dan profesi (non komersial) semisal akuntan, advokat, kontraktor, dan lainnya. Dalam perkembangannya justru kemitraan non komersial yang berkembang pesat, yaitu kegiatan menjalankan profesi.

\section{Tinjauan Umum Mengenai Konsorsium a. Pengertian Konsorsium}

Konsorsium dalam Kamus Besar Bahasa Indonesia adalah himpunan beberapa pengusaha yang mengadakan usaha bersama/pengkongsian. Konsorsium biasa di kenal di kalangan pengusaha jasa konstruksi dengan Kerja Sama Operasi/Joint Operation (non integrated system/nonadministrative/bukan badan hukum). Konsorsium adalah suatu kesepakatan bersama subjek hukum untuk melakukan suatu pembiayaan, atau kesepakatan bersama antara subjek hukum untuk melakukan suatu pekerjaan bersama-sama dengan porsi-porsi pekerjaan yang sudah di tentukan dalam perjanjian. Konsorsium dalam Hukum Dagang termasuk kedalam Persekutuan Perdata (Maatschap). Perlu dipahami bahwa persekutuan perdata (Maatschap) bukanlah suatu badan hukum atau rechtpersoon, melainkan hanya dilahirkan dari perjanjian-perjanjian para pendirinya saja (subjek-subjek Hukum). Hal ini ditegaskan pula dalam Pasal 1618 KUHPerdata, di mana ditentukan bahwa persekutuan itu adalah suatu perjanjian dimana dua orang atau lebih mengikatkan diri untuk memasukan 
sesuatu kedalam persekutuan, dengan maksud membagi keuntungan yang terjadi karenanya.

Pada dasarnya konsorsium merupakan suatu perjanjian antara dua pihak atau lebih. Mengenai pengertian mengenai konsorsium ini juga ditentukan dalam Keputusan Presiden No. 54 Tahun 2010 tentang Pengadaan Barang /Jasa Pemerintah, dalam pasal 21 ayat 1 ditentukan bahwa:

"dalam hal sifat dan lingkup kegiatan Pengadaan Barang/Jasa terlalu luas, atau jenis keahlian yang diperlukan untuk menyelesaikan kegiatan tidak dapat dilakukan oleh 1 (satu) Penyedia Barang/Jasa, maka dalam pelaksanaan Pengadaan Barang/Jasa diberikan kesempatan yang memungkinkan para Penyedia Barang/Jasa saling bergabung dalam suatu konsorsium atau bentuk kerja sama lain".

Konsorsium bisa dilakukan antara perusahaan-perusahaan lokal atau pun perusahan lokal dengan perusahaan asing. Salah satu contoh yang dapat kita lihat untuk konsorsium antara perusahan lokal dengan asing adalah dalam kasus tender pengadaan kapal, pengadaan bis kota, pengadaan jalan tol, dan sebagainya.

Beberapa penulis mengemukakan bahwa konsorsium merupakan suatu Kerja Sama Operasi/Joint Operation. Perihal Kerja Sama Operasi (KSO) tertuang dalam PSAK 39 (Pernyataan Standar Akutansi Keuangan), yaitu perjanjian antara dua pihak atau lebih, di mana masing-masing sepakat untuk melakukan suatu usaha bersama dengan menggunakan aset dan atau hak usaha yang dimiliki dan secara bersama menanggung risiko usaha tersebut. PSAK 39 pada dasarnya telah dicabut (ED-PPSAK 11), akan tetapi definisi KSO di dunia usaha tidak berbeda dengan definisi yang disebutkan dalam PSAK 39 diatas. ${ }^{13}$

Joint operation adalah merupakan perkumpulan dua badan atau lebih yang bergabung untuk menyelesaikan suatu proyek, penggabungan ini bersifat sementara sampai proyek tersebut selesai. Pada dasarnya JO dapat terbagi menjadi dua tipe yaitu Administrative dan Non-Administrative JO, Non-Administrative JO ini lah yang kemudian dalam praktik jasa konstruksi disebut konsorsium. Administrative JO sering juga disebut sebagai Kerja Sama Operasi (KSO) di mana kontrak dengan pihak pemberi kerja atau Project Owner ditandatangani atas nama JO. Dalam hal ini JO dianggap seolah-olah merupakan entitas tersendiri terpisah dari perusahaan para anggotanya. Tanggung jawab pekerjaan terhadap pemilik proyek berada pada entitas JO, bukan pada masing-masing anggota JO. Masalah pembagian modal kerja atau pembiayaan proyek, pengadaan peralatan, tenaga kerja,

\footnotetext{
${ }^{13}$ Priyanto Rustadi, Perpajakan Joint Operation Usaha Jasa Konstruksi, Mei 2014
} 
biaya bersama (joint cost) serta pembagian hasil (profit sharing) sehubungan dengan pelaksanaan proyek didasarkan pada porsi pekerjaan (scope of work) masing-masing yang disepakati dalam sebuah Joint Operation Agreement. ${ }^{14}$

Sementara, bentuk Non-Administrative JO dalam praktiknya di kalangan pengusaha jasa konstruksi sering disebut sebagai Konsorsium di mana kontrak dengan pihak Project Owner di buat langsung atas nama masing-masing perusahaan anggota. Dalam hal ini JO hanya bersifat sebagai alat koordinasi. Tanggung jawab pekerjaan terhadap Project Owner berada pada masing-masing anggota. ${ }^{15}$ Dengan kata lain, dalam hal ini suatu konsorsium itu pada dasarnya adalah bentuk persekutuan antara dua pihak atau lebih yang terwujudkan dalam suatu perjanjian bersama, maka masingmasing pihak bertanggung jawab atas perjanjian tersebut.

\section{b. Dasar Hukum Pembentukan Konsorsium}

Dasar hukum dalam pembentukan konsorsium sebagai suatu perjanjian tidak lepas dari syarat sahnya suatu perjanjian sebagaimana diatur dalam Pasal 1320 KUHPerdata juncto 1338 KUHPerdata. Untuk sahnya suatu perjanjian sebagaimana ditentukan dalam Pasal 1320 harus memenuhi syarat subyektif dan syarat obyektif. Syarat subyektif suatu perjanjian berkaitan dengan subyek hukum yang melakukan perjanjian tersebut, yakni para pihak harus sepakat mengikatkan dirinya, dalam hal ini ada asas konsensualisme. Juga, para pihak harus memiliki kecakapan untuk membuat perikatan, artinya seseorang itu dipandang mampu menanggung hak dan kewajibannya, yakni mereka sudah dewasa dan tidak di bawah pengampuan. Ditegaskan pula dalam Pasal 1338 KUHPerdata, bahwa semua perjanjian yang dibuat secara sah berlaku sebagai undang-undang bagi mereka yang membuatnya. Dalam hal ini berlaku asas pacta sunt servanda, yang berarti karena kesepakatan yang dibuat oleh para pihak maka perjanjian itu mengikat mereka layaknya undang-undang. Konsekuensi dari pasal tersbut juga menunjukkan adanya asas kebebasan berkontrak didalamnya.

\section{Analisis Kasus Perjanjian Konsorsium antara PT Agro Bintang Dharma Nusantara dengan Pemerintah Daerah Balikpapan, Bontang, Kutim dan Paser}

\section{a. Tanggung Jawab Sekutu Maatschap terhadap Pihak Ke-3 dalam Suatu Perjanjian Konsorsium}

Perjanjian konsorsium yang dilakukan oleh para pihak dalam kasus ini adalah mengenai perjanjian konsorsium pengadaan kapal feri cepat.

\footnotetext{
${ }^{14}$ www.ORTax.org, Ruston Tambunan, Ak.,M.Si.,M.Int.Tax

15 Priyanto Rustadi, Perpajakan Joint Operation Usaha Jasa Konstruksi, Mei 2014
} 
Konsorsium kapal feri cepat beranggotakan Balikpapan, Bontang, Kutai Timur dan Paser dengan PT Argo Bintang Darma Nusantara dalam hal melakukan perjanjian kerja sama nomor 021/ABDN-Dir/SPK/X/01 tanggal 4 Oktober 2001, untuk pengadaan jasa pelayanan kapal cepat "water jet feri" Trans Kalimantan Timur. Kapal direncanakan untuk alat transportasi yang akan menghubungkan empat daerah tersebut. Di dalam perjanjian itu, menyatakan bahwa para pihak sepakat untuk melaksanakan pengadaan jasa pelayanan kapal cepat dengan total biaya investasi sebesar AS \$4 juta (sekitar Rp 40 miliar). Masing-masing pihak yang melakukan kerja sama menginvestasikan sebesar 20\% dengan kewajiban penyertaan modal masingmasing 800.000 dolar AS atau sekitar IDR 8,2 miliar.

Pengadaan kapal yang saat itu ditujukan untuk memberikan jasa angkutan cepat kepada masyarakat, namun belakangan pengadaan kapal ternyata dinilai bermasalah. Kapal yang dibeli adalah kapal bekas dengan kondisi yang tidak layak. Hal ini menyebabkan, kapal tersebut hanya sempat sekali beroperasi. Selain dari pada itu, Badan Pemeriksa Keuangan selalu mencantumkan investasi kapal feri cepat dalam opini audit keuangan daerah tiap tahunnya, sehingga membuat Balikpapan selalu mendapat opini wajar dengan pengecualian (WDP). Direktur PT Agro Bintang, yaitu Budi Handoko bahkan sempat ditahan disel tahanan terkait penyimpangan yang terjadi dalam pengadaan kapal tersebut. Pada akhirnya empat daerah yang melakukan konsorsium bersepakat untuk membubarkan perjanjian konsorsium yang mereka lakukan, hanya saja pihak PT Agro Bintang sempat tidak menyepakati pembubaran perjanjian tersebut, hingga akhirnya pada Agustus 2014 perjanjian konsorsium itu resmi dibubarkan. Pembubaran konsorsium ini juga diikuti dengan melikuidasi aset-aset yang dimiliki, yang akan dijual kepada pihak lainnya untuk kemudian dibagikan kepada masingmasing kabupaten/kota yang terlibat dalam konsorsium ini. ${ }^{16}$

Pasal 1646, Buku ke IV KUHPerdata menentukan mengenai macammacam cara berakhirnya suatu persekutuan, yaitu persekutuan berakhir dikarenakan:

1) Lewatnya waktu untuk mana persekutuan telah diadakan;

2) Musanahnya barang atau diselesaikannya perbuatan yang menjadi pokok persekutuan;

3) Atas kehendak semata dari beberapa atau seorang sekutu;

4) Jika seorang sekutu meninggal atau ditaruh dibawah pengampuan, ataupun dinyatakan pailit.

\footnotetext{
${ }^{16} \mathrm{https}: / / \mathrm{www} \cdot$ google $\cdot \operatorname{co} \cdot \mathrm{id} / \mathrm{url}$ ?sa $=\mathrm{t} \& \mathrm{rct}=\mathrm{j} \& \mathrm{q}=\& \mathrm{esrc}=\mathrm{s} \&$ source= $=\mathrm{web} \& \mathrm{~cd}=3 \& \mathrm{cad}=\mathrm{rja} \& u a c t=$ $8 \&$ ved=0CCkQFjACahUKEwj6mremp5vIAhWUA44KHQkrDPc\&url=http $\% 3 \mathrm{~A} \% 2 \mathrm{~F} \% 2 \mathrm{~F}$ www.tribunnews.com\%2Fregional\%2F2014\%2F08\%2F02\%2Fkonsorsium-kapal-fericepat-akhirnya dibubarkan\&usg=AFQjCNFSJgh-xWBYYAiWIEcK2KqHW-MI5Q
} 
Adapun alasan berakhirnya perjanjian konsorsium pengadaan kapal feri cepat dalam kasus ini, dikarenakan beberapa pihak mengkhendaki bubarnya persekutuan tersebut. Hal ini tentu logis, mengingat bahwa dasar dari ternemtuknya persekutuan atau kemitraan tersebut karena adanya kesepakatan oleh para sekutu untuk mengikatkan diri. Jika, salah satu ataupun beberapa pihak mengkhendaki persekutuan berakhir, maka dengan sendirinya kesepakatan mengikatkan diri juga sudah tidak lagi ada dan hubungan kemitraan berakhir. Namun, meskipun perjanjian berakhir atas manfaat atau keuntungan yang diperoleh para sekutu dalam persekutuan tidak serta merta mengakhiri kewajibannya kepada pihak ketiga yang belum tertuntaskan.

Perlu diketahui bahwa tujuan kerjasama dalam suatu persekutuan adalah jelas untuk memperoleh suatu keuntungan atau manfaat dari hasil kerjasama, tidak ada suatu kerjasama yang sengaja dibuat untuk tidak mendatangkan kemanfaaatan. Dalam perjanjian konsorsium yang dilakukan ini, pengadaan kapal feri cepat jelas ditujukan dalam upaya mengadakan alat transportasi yang akan menghubungkan empat daerah yang melakukan kerjasama tersebut. Karena proyek yang dilakukan adalah dalam skala besar yang membutuhkan modal yang tidak sedikit, maka daerah-daerah tersebut melakukan perjanjian konsorsium dengan PT Agro Bintang. Perjanjian berupa investasi untuk memasukkan modal guna membeli kapal feri dari pihak ke tiga. Beriringan dengan itu, sudah pasti selain ada para sekutu dalam perjanjian konsorsium, peran pihak ketiga terdapat pula dalam kerjasama ini. Seperti, pembelian kapal feri kepada perusahaan pembuat kapal, perusahaan pembiayaan, dan dapat juga pihak perbankan. Karena adanya interaksi tersebut, maka muncul pula tangung jawab antara para sekutu dengan pihak ketiga, yang manakala perjanjian dibubarkan tanggung jawab itu tidak serta merta hilang.

Tanggung jawab terhadap pihak ketiga diatur pada pasal 1642-1645, yang dapat disimpulkan sebagai berikut:

1) prinsip umum, anggota para sekutu tidak terikat dan tidak bertanggung jawab untuk seluruh utang persekutuan, dan masing-masing anggota sekutu tidak dapat mengikat anggota sekutu yang lain, jika mereka tidak diberikan kuasa untuk melakukan hal itu. Dengan demikian sesuai dengan prinsip umum ini, yang bertanggung jawab kepada pihak ketiga, hanya anggota sekutu yang melakukan tindakan hukum itu, dan tanggung jawab ini bersifat pribadi; dan

2) apabila para anggota sekutu bersama-sama melakukan tindakan hukum dengan pihak ketiga, maka pihak ketiga dapat menuntut mereka masing- 
masing untuk jumlah dan bagian yang sama meskipun bagian anggota sekutu yang satu kurang dari bagiaan anggota sekutu yang lain. ${ }^{17}$

Ketentuan dalam pasal 1642-1645 KUHPerdata jelas menunjukkan bahwa adanya personal liability dan unlimitid liability. Personal liability di sini menunjuk pada tanggung jawab yang bersifat pribadi dan melekat pada masing-masing anggota dalam persekutuan tersebut, bukan pada persekutuannya. Sebab, persekutuannya adalah bentuk perjanjian dan bukan badan hukum yang membawa hak dan kewajiban. Sementara, unlimited liability dalam hal ini menunjuk pada tanggung jawab dari masing-masing anggota tidak dibatasi sebesar jumlah modal yang mereka masukan dalam usaha tersebut, melainkan tanggung jawab dapat menyentuh hingga harta pribadi anggota persekutuan tersebut.

\section{b. Perihal Gugatan terhadap Konsorsium}

Seperti telah dijelaskan di atas, esensi dari konsorsium adalah suatu persekutuan perdata (maatschap) yang lahir dari persetujuan antara subjeksubjek hukum sesuai dengan ketentuan Pasal 1320 juncto 1338 KUHPerdata. Dengan demikian, konsorsium bukanlah merupakan badan hukum atau subjek hukum, namun hanya merupakan bentuk kerja sama antara anggotanya (subjek hukum) yang mempunyai tujuan sama, dan oleh karenannya setiap anggota-anggota konsorsium bertanggung jawab atas setiap perbuatan yang dilakukannya. Karena konsorsium bukanlah suatu subjek hukum, maka tuntutan-tuntutan pihak ketiga tidak dapat ditujukan kepada konsorsium melainkan kepada masing-masing anggota konsorsium yang dinilai telah menimbulkan kerugian kepada pihak ketiga tersebut. Dalam hal ini kembali menunjukkan tanggung jawab dari maatchap/ partnership yang unlimited (tangung jawab yang tidak terbatas).

Gugatan dalam perjanjian konsorsium ataupun persekutuan, hanya dapat diajukan kepada anggotanya bukan konsorsiumnya. Hal ini kembali menekankan bahwa konsorsium bukanlah badan hukum, dengan kata lain, persekutuan meupakan bentuk kerja sama perdata, bukan badan hukum. Terdapat bebearapa karakteristik yang membedakan suatu persekutuan dengan badan hukum.

Partners have unlimited liability for the obligations of the buisness. If the business becomes insolvent, business creditors may require a partner to pay a partnership liability from her individuals assets, such as her house and her bank accounts. ${ }^{18}$ Tanggung jawab yang tidak terbatas melekat pada anggota persekutuan tersebut, yang artinya anggota persekutuan tanggung

\footnotetext{
${ }^{17}$ Op.Cit., M. Yahya Harahap, hlm. 4.

18 Metzger, dkk., Business Law and The Regulatory Environment (Consept and Case), (Illinois: IRWIN, 1986), hlm. 389.
} 
jawabnya tidak terbatas hanya sebesar modal yang dimasukkannya ke dalam persekutuan, akan tetapi juga meliputi harta pribadinya.

Each partner has right to manage the buisness. ${ }^{19}$ Seorang mitra/sekutu dalam suatu persekutuan kedudukannya adalah sama-sama pemilik dan pengurus. Tidak ada suatu sekutu yang menjadi majikan dari sekutu yang lain. Hal ini sekaligus menunjukkan karakter dari suatu persekutuan yang didalamnya terdiri dari sekutu-sekutu yang bertangung jawab secara bersama dan tidak dibatasi perbedaan tanggung jawabnya dalam suatu persekutuan. Sebuah kasus dapat menjadi gambaran mengenai deskripsi tersebut. Kasus antara Ford v Mitcham. ${ }^{20}$ Dalam kasus tersebut W.M. Ford dan James D. Mitcham merupakan partner dalam usaha konstruksi. Suatu kejadian menyebabkan Ford meninggal ketika bekerja. Atas meninggalnya Forrd, istrinya menggugat atas kompensasi kecelakaan kerja yang menimpa suaminya. Mitcham menetang klaim tersebut atas dasar hubungan yang terjadi antara dirinya dan Ford. Ia berdalih bahwa Ford adalah partnernya dan bukan pegawainya, sehingga klaim tersebut ia anggap tidak tepat. Putusan pengadilan sendiri, membenarkan dalih Mitcham, dengan alasan yang sama. Ketika sekutu dalam persekutuan melakukan pekerjaan ia adalah seorang partner dan bukanlah pegawai yang dikontrol oleh majikannya/pengusaha. Ini menunjukkan bahwa sekutu memiliki kedudukan yang sama dalam persekutuan, sehingga mereka bersama-sama pula menanggung perbuatan hukum terhadap pihak ke tiga.

Alasan mengapa para sekutu dalam perjanjian bertanggung jawab secara bersama dalam hal terjadi gugatan ataupun tuntutan dari pihak ketiga pada dasarnya adalah mengingat bentuk dasar persekutuan sebagai suatu kemitraan. Pada dasarnya pengurusan persekutuan diatur dalam Pasal 6361639 KUHPerdata. Pengurusan yang tertera dalam KUHPerdata yaitu berdasarkan pasal 1637 KUHPerdata menentukan bahwa:

a) memungkinkan masing-masing anggota peserta persekutuan mempunyai wewenang untuk melakukan semua hal yang berhubungan dengan tugas pengurusan persekutuan; dan

b) kecuali ada perjanjian yang membatasi berupa klausul bahwa setiap tindakan pengurusan harus sepengetahuan anggota pengurus.

Pengurusan berdasarkan pasal 1638 KUHPerdata; pengurusan atas bantuan pengurusan lain:

a) berdasarkan kesepakatan, pengurusan dilakukan bersama-sama; dan

b) pengurusan yang satu tidak dapat bertindak tanpa bantuan pengurusan lain.

${ }^{19}$ Ibid., hlm. 388.

${ }^{20}$ Ronald A. Anderson, Business Law, (Ohio: South Western Publishing Co., 1980), hlm. 585. 
Masing-masing anggota sekutu atau para sekutu dari persekutuan, boleh melakukan pengurusan dengan cara berikut: ${ }^{21}$

a) semua anggota sekutu atau para sekutu dianggap berwenang melakukan pengurusan (management) dengan saling bergantian;

b) tindakan anggota sekutu tersebut mengikat sekutu yang lain, meskipun tindakan itu dilakukan tanpa inzin dan persetujuannya;

c) setiap sekutu berwenang mewajibkan anggota sekutu yang lain memikul biaya untuk keperluan persekutuan; dan

d) Anggota sekutu yang tidak memunyai hak pengurusan, tidak boleh mengasingkan benda-benda maupun menggadaikan atau membebaninya.

Karakteristik lainnya yang juga mencirikan persekutuan adalah pada "generally, a partnership has no life apart from its owner."22 Sejatinya suatu perjanjian yang melekat pada pribadi sekutu tersebut, maka ketika salah seorang partner meninggal maka persekutan akan bubar dan dihentikan. Karakteristik ini kembali menunjukkan bahwa sejatinya persekutuan memang bukan badan hukum, melainkan suatu perjanjian yang dilakukan oleh seseorang dengan orang lain. Maka dapat disimpulkan bahwa jika ingin menggugat persekutuan, gugatan hanya bisa ditujukan kepada anggota persekutuan bukan persekutuan tersebut.

Dalam suatu persekutuan (dalam hal ini perjanjian konsorsium) tidak melekat karakteristik badan hukum. Sebab tidak ada pemisahan kekayaan antara kekayaan sekutu dengan kekayaan perseroan. Sehingga, gugatan tidak dapat diajukan kepada persekutuannya, melainkan subyek hukum yang melakukan perjanjian tersebut. Dikarenakan tidak adanya pemisahan kekayaan persekutuan dengan kekayaan pemilik, maka anggota secara pribadi bertanggung jawab secara tidak terbatas. Artinya, pihak ke tiga dapat menggugat ganti kerugian hingga meliputi kekayaan pribadi anggota sekutu.

\section{Penutup}

Pasal 1646, Buku ke IV KUHPerdata menentukan mengenai macammacam cara berakhirnya suatu persekutuan, salah satunya yaitu persekutuan berakhir dikarenakan karena kehendak salah satu atau beberapa pihak. Berakhirnya kesepakatan secara otomatis juga mengakhiri perjanjian yang dibuat oleh para pihak. Namun, tanngung jawabnya terhadap pihak ke-3 tidak serta merta berakhir. Tanggung jawab terhadap pihak ketiga diatur pada pasal 1642-1645, yang dapat disimpulkan sebagai berikut:

a) prinsip umum, anggota para sekutu tidak terikat dan tidak bertanggung jawab untuk seluruh utang persekutuan, dan masing-masing anggota sekutu tidak dapat mengikat anggota sekutu yang lain, jika mereka tidak

${ }^{21}$ Op.Cit., M. Yahya Harahap, hlm. 4.

22 Op.Cit., Metzger, dkk, hlm. 389. 
diberikan kuasa untuk melakukan hal itu. Dengan demikian sesuai dengan prinsip umum ini, yang bertanggung jawab kepada pihak ketiga, hanya anggota sekutu yang melakukan tindakan hukum itu, dan tanggung jawab ini bersifat pribadi.

b) apabila para anggota sekutu bersama-sama melakukan tindakan hukum dengan pihak ketiga, maka pihak ketiga dapat menuntut mereka masingmasing untuk jumlah dan bagian yang sama meskipun bagian anggota sekutu yang satu kurang dari bagiaan anggota sekutu yang lain.

Lalu, perihal gugatan yang diajukan kepada persekutuan/konsorsium adalah tidak dapat dilakukan. Mengingat, esensi dari konsorsium adalah suatu persekutuan perdata (maatschap) yang lahir dari persetujuan antara subjek-subjek hukum sesuai dengan ketentuan Pasal 1320 juncto 1338 KUHPerdata. Dengan demikian, konsorsium bukanlah merupakan badan hukum atau subjek hukum, namun hanya merupakan bentuk kerja sama antara anggotanya (subjek hukum) yang mempunyai tujuan sama, dan oleh karenannya setiap anggota-anggota konsorsium bertanggung jawab atas setiap perbuatan yang dilakukannya. Karena konsorsium bukanlah suatu subjek hukum, maka tuntutan-tuntutan pihak ketiga tidak dapat ditujukan kepada konsorsium melainkan kepada masing-masing anggota konsorsium yang dinilai telah menimbulkan kerugian kepada pihak ketiga tersebut. Dalam hal ini kembali menunjukan tanggung jawab dari maatchap/ partnership yang tidak terbatas.

\section{Daftar Pustaka}

\section{A. Buku-Buku:}

Djoko Prakoso \& Bambvang Riyadi, 1987, Dasar Hukum Persetujuan Tertentu di Indonesia, Jakarta: PT. Bina Aksara.

Johannnes Ibrahim, 2006, Hukum Organisasi Perusahaan: Pola Kemitraan dan Badan Hukum, Bandung: Refika Aditama.

Priyanto Rustadi, Perpajakan Joint Operation Usaha Jasa Konstruksi, Mei 2014

Mulhadi, 2010, Hukum Perusahaan (Bentuk-Bentuk Badan Usaha di Indonesia), Bogor: Penerbit Ghalia Indonesia

M. Yahya Harahap, 2013, Hukum Perseroan Terbatas, Cet IV, Jakarta: Sinar Grafika

Ridwan Khairandi, 2013, Pokok-Pokok Hukum Dagang Indonesia, FH UII Press, Yogyakarta

Ronald A. Anderson, 1980, Business Law, Ohio: South Western Publishing Co 
Romli atmasasmita, 2014, Hukum Kejahatan Bisnis (Teori dan Praktik di Era Globalisasi), Bogor:Penerbit Kencana

Subekti, 2005, Hukum Perjanjian, Jakarta: PT Intermasa

Sudikno mertokusumo, 2012, Teori Hukum, Yogyakarta: Atma Jaya Yogyakarta

\section{B. Peraturan Perundang-Undangan:}

Kitab Undang-Undang Hukum Perdata

Kitab Undang-Undang Hukum Dagang

Keputusan Presiden No. 54 Tahun 2010 tentang Pengadaan Barang/Jasa Pemerintah

\section{Internet:}

www.ORTax.org, Ruston Tambunan, Ak.,M.Si.,M.Int.Tax, diakses tanggal 19 September 2015

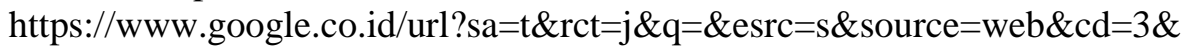
cad $=$ rja\&uact $=8 \& v e d=0 C C k Q F j A C a h U K E w j 6 m r e m p 5 v I A h W U A 44$ KHQkrDPc\&url=http\%3A\%2F\%2Fwww.tribunnews.com\%2Fregiona $1 \% 2 \mathrm{~F} 2014 \% 2 \mathrm{~F} 08 \% 2 \mathrm{~F} 02 \% 2 \mathrm{Fkonsorsium}$-kapal-feri-cepatakhirnyadibubarkan\&usg=AFQjCNFSJghxWBYYAiWIEcK2KqHW-MI5Q, diakses tanggal 17 September 2015

http://m.tribunews.com/regional/2013/11/10/pemkab-kutim-telusuriinvestasi-bintang-kaltim-transport, daikses tanggal 17 September 2015 